\title{
INFARCTION IN THE YOUNG - A CLINICAL CASE REPORT
}

\author{
Cristian Moise ${ }^{1,2}$, Denisa Predețeanu ${ }^{1,2}$, Andra Bălănescu ${ }^{1,2}$, Violeta Bojincă ${ }^{1,2}$, \\ Grigorie Baloșin ${ }^{1}$, Ruxandra Ionescu, \\ "Saint Mary" Clinical Hospital, Bucharest, Romania \\ 2"Carol Davila" University of Medicine and Pharmacy, Bucharest, Romania \\ Corresponding author: \\ Cristian Moise, Internal Medicine and Rheumatology Department, "Saint Mary" Clinical \\ Hospital \\ 37-39 Ion Mihalache Blvd. 011172, Sector 1, Bucharest, Romania \\ E-mail: moise.de.cristian@gmail.com
}

\begin{abstract}
We present the case of a 34-year-old male who suddenly experienced upper right quadrant abdominal pain of medium-high intensity that radiated towards his right lumbar area and right testicle, accompanied by nausea and vomiting. His personal history was significant for having an eye prosthesis implanted when he was three years old, due to structural degradation of undetermined cause in his left eye.

He was first seen by a surgeon who recommended an abdominal CT scan and an urology consultation. In the urology clinic, renal and testicular ultrasounds were normal and he was prescribed symptomatic medication.

Due to the pain escalating, the patient underwent a contrast CT scan of the abdomen and pelvis that revealed two renal infarction lesions in the middle and inferior thirds of the right kidney.

The patient was admitted and anticoagulants and pain medication were started. A full body CT scan did not reveal any other abnormalities. Tumour markers and genetic thrombophilia markers were sent for analysis. He was referred to a nephrology clinic, where he underwent screening for multiple myeloma and vasculitic/autoimmune causes, with negative results. $A$ contrast renal vascular ultrasound of the right kidney identified the obstructions as being in the middle and inferior interlobar veins.

Afterwards, the genetic tests revealed three thrombophilic mutations - factor $V$ Leiden positive homozygote, MTHFR C677T and A1298C both positive heterozygote. This might have also been the cause of the childhood ocular surgery. The patient continued anticoagulation with apixaban, with no further significant medical events to this day.
\end{abstract}

Keywords: factor $V$ Leiden, MTHFR, NOAC, renal infarction, thrombophilia, upper right quadrant abdominal pain. 


\section{INTE}

\section{Rezumat}

Prezentăm cazul unui pacient în vârstă de 34 ani ce se prezintă la o clinică privată pentru durere în hipocondrul drept, cu iradiere lombară dreaptă și către testiculul drept, debutată brusc, de intensitate medie-mare, însoțită de greață și vărsături. Din antecedentele personale patologice menționăm protezarea ochiului stâng, la 3 ani, pentru degradarea structurilor acestuia, de cauză neprecizată.

Este consultat prima oară de către un medic chirurg, care îi recomandă consult de urologie și CT abdomino-pelvin. În clinica de urologie efectuează ecografie renală și testiculară (normale) și i se recomandă simptomatice.

Întrucât durerea s-a intensificat, pacientul efectuează CT abdomino-pelvin cu substanță de contrast, care decelează 2 leziuni de infarct renal în treimile medie și inferioară ale rinichiului drept.

Pacientul este internat și se ințiază anticoagulante și antialgice. Se efectuează CT toraceabdomen-pelvis (fără elemente patologice suplimentare) și se recoltează markeri tumorali și markeri genetici pentru trombofilie. Este consultat ulterior într-o clinică de nefrologie, unde se efectuează screening pentru mielom multiplu și pentru o cauză vasculitică/autoimună, cu rezultate negative. Efectuează ecografie cu contrast de vase renale drepte, care indentifică obstrucția la nivelul venelor interlobare medie și inferioară.

Ulterior, sunt finalizate testele genetice, care decelează trei mutații trombofilice - factor $V$ Leiden pozitiv homozigot, MTHFR C677T și A1298C, ambele pozitive heterozigot. Este posibil ca protezarea oculară să fie tot în contextul trombofiliei. Pacientul continuă anticoagularea cu apixaban, cu evoluție bună până în prezent.

Cuvinte cheie: factor V Leiden, MTHFR, NOAC, infarct renal, trombofilie, durere abdominală în cadranul superior drept. 


\section{Introduction}

The term "infarction" is used to define the pathological process of cell necrosis caused by a mismatch between the requirements and the supply of oxygen. This most commonly occurs in the myocardium and in elderly people, with significant atherothrombotic risk factors, due to the rupture of an atheromatous plaque. However, infarction can occur in other organs (such as the kidney) and in young people as well, due to a large variety of causes that include emboli, autoimmune diseases, genetic predispositions, paraneoplastic syndromes and anatomical congenital abnormalities ${ }^{(1)}$. In these cases, the diagnosis may be difficult to obtain, as the symptoms can be rather nonspecific and extensive imaging and laboratory analyses are required. However, clinicians should make all possible efforts to fully investigate the issue, as the evolution can be very dramatic without proper treatment ${ }^{(2)}$.

\section{Case report}

We present the case of a 34-year-old Caucasian man with sudden onset of abdominal pain in the right upper quadrant, radiating posteriorly, towards his right lumbar area, of medium-high intensity and accompanied by nausea and vomiting. His personal medical history was significant for having undergone eye replacement surgery when he was 3 years old, due to severe and quickly progressive loss of vision and structural degradation in his left eye. A hydroxyapatite eye prosthesis was implanted, with the micro-reinsertion of the ocular muscles, with favourable outcome and evolution. His family history was significant only for type 2 diabetes mellitus (mother).

The patient was first consulted in a private surgery practice, where he received a dose of intramuscular non-steroidal antiinflammatory drug (NSAID) (completely inefficient) and was advised to undertake an abdominal CT scan and an urology consultation, especially since the pain was beginning to radiate towards his right testicle. The urology consultation did not find ultrasound signs of testicular or renal pathologies and labelled the episode as a simple abdominal colic, recommending symptomatic medication (NSAIDs, drotaverine, etc.)

Due to the pain escalating in intensity, despite medication, the patient underwent a contrast computer tomography (CT) of the abdominal and pelvic regions. The $\mathrm{CT}$ scan revealed an enlarged liver (cranio-caudal diameter $20 \mathrm{~cm}$ ) with a small hypo-dense, hypoenhanced lesion in segment VI $(14 / 10 \mathrm{~mm}$ in diameter), suggestive of a haemangioma. However, it also revealed two extensive triangular areas, non-enhanced by contrast, at the level of the anterior valve, in the middle and inferior thirds of the right kidney (figures 1 and 2), suggestive of renal infarction areas. No defects of the major abdominal blood vessels were noted.

He was admitted to the urology department of a private hospital for further investigations and treatment. Upon admission his blood pressure was $150 / 110 \mathrm{mmHg}$, heart rate was $70 \mathrm{bpm}$ and the characteristics of his pain were unmodified by putting pressure anywhere on the abdomen nor by the Giordano manoeuvre; the rest of the clinical examination was unremarkable. He had a high white blood cell (WBC) count - 14970 cells/microliter, with $85.6 \%$ neutrophils - 12 810 cells/microliter, an elevated $C$ reactive protein level - $8 \mathrm{mg} / \mathrm{L}$ (ULN 5mg/L), which rose to $146 \mathrm{mg} / \mathrm{L}$ within 2 days, and a slightly elevated LDH level - 336 U/L (ULN 225 U/L). Haemoglobin levels, platelet count, creatinine, BUN, liver enzymes, blood 


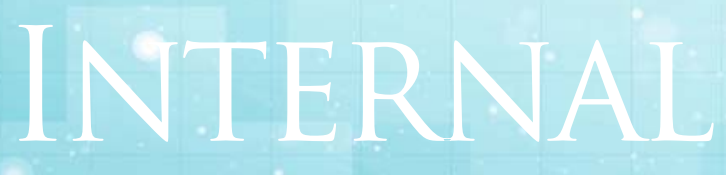

Clinical cases

glucose, prothrombin time (PT), INR, activated partial thromboplastin time (aPTT) and fibrinogen were all normal.

Urinalysis revealed a slightly lower specific gravity - 1.005 (RI 1.010-1.030) and a high concentration of ketone bodies - $50 \mathrm{mg} / \mathrm{dl}$ (ULN $4 \mathrm{mg} / \mathrm{dl}$ ), without any excess WBC, red blood cells $(R B C)$, nitrates, proteins or glucose. ECG showed no abnormalities (including 48h Holter monitoring), nor did the transthoracic echocardiography that was performed (no rhythm aberrations, no signs of thrombi, no structural or functional defects). A new contrast-enhanced CT scan was performed, full body, revealing no other abnormalities than the previous one. Genetic markers for thrombophilia and tumour markers were sent for processing.

The patient received anticoagulation therapy, first with bolus $5000 \mathrm{UI}$ sodium dalteparine, then with enoxaparine $80 \mathrm{mg}(1 \mathrm{mg} / \mathrm{kgc}$ ) b.i.d. and a combination of intravenous pain medications (acetaminophen, sodium metamizole, tramadol) as needed, with the pain gradually subsiding and becoming mild within two days. He was discharged with the recommendation to continue anticoagulant therapy, along with pain medications and 7 days of cefixime $400 \mathrm{mg}$ q.d. It was also recommend that he follow up with evaluations in a nephology and in a rheumatology clinic.

The patient was first evaluated in a nephrology clinic, where he underwent screening for multiple myeloma - serum free light kappa and lambda chains within normal limits, as well as for a possible vasculitis cause - anti nuclear antibodies (Ab), anti DNAds $A b$, anti SS-A Ab, anti SS-B Ab, anti Sm Ab, CANCA, P-ANCA, anti-glomerular membrane base (GMB) Ab, anti-cardiolipine Ab IgG and $\lg \mathrm{M}$, all were negative. Afterwards, a contrast renal vascular ultrasound of the right kidney was performed which showed signs of thrombosis in the middle and inferior interlobar renal veins and small perirenal liquid collections.

Soon after this, the thrombophilia genetic test results came in and revealed that the patient was positive for the factor $\mathrm{V}$ Leiden mutation (homozygote) and for two methylenetetrahydrofolate reductase (MTHFR) gene mutations C677T and A1298C (heterozygote) and was negative for the G20210A prothrombinic factor II mutation. Tumour markers were also negative. The patient has since been on oral anticoagulation therapy with apixaban $(5 \mathrm{mg}$ b.i.d. for 3 months and then 2,5mg b.i.d. indefinitely), which he chose for himself, declaring that he fully understands the risks, lack of evidence and unknown efficacy of direct oral anticoagulants in thrombophilia. He has not experienced any further significant medical events since then. In addition, his brother also underwent testing and is positive for the factor $V$ Leiden mutation (homozygote) and for one of the MTHFR mutations (heterozygote). He is also taking prophylactic therapy with apixaban, per his will. 


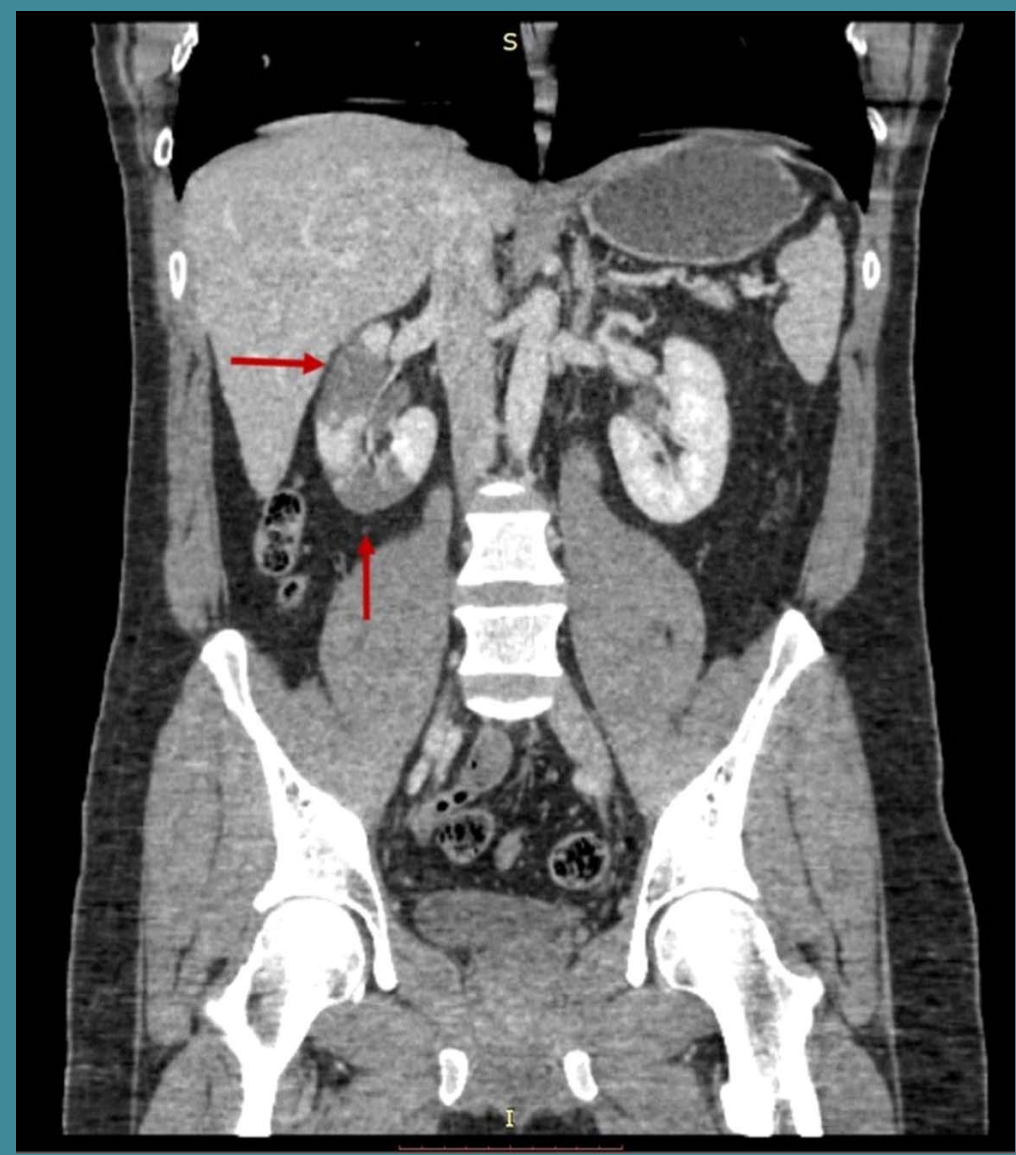

Figure 1. Contrast-enhanced CT scan of the abdomen and pelvis, coronal section, venous phase; two focal triangular hypo-enhanced lesions can be observed (red arrows) that involve both the cortical and the medullar areas, highly suggestive of renal infarctions.

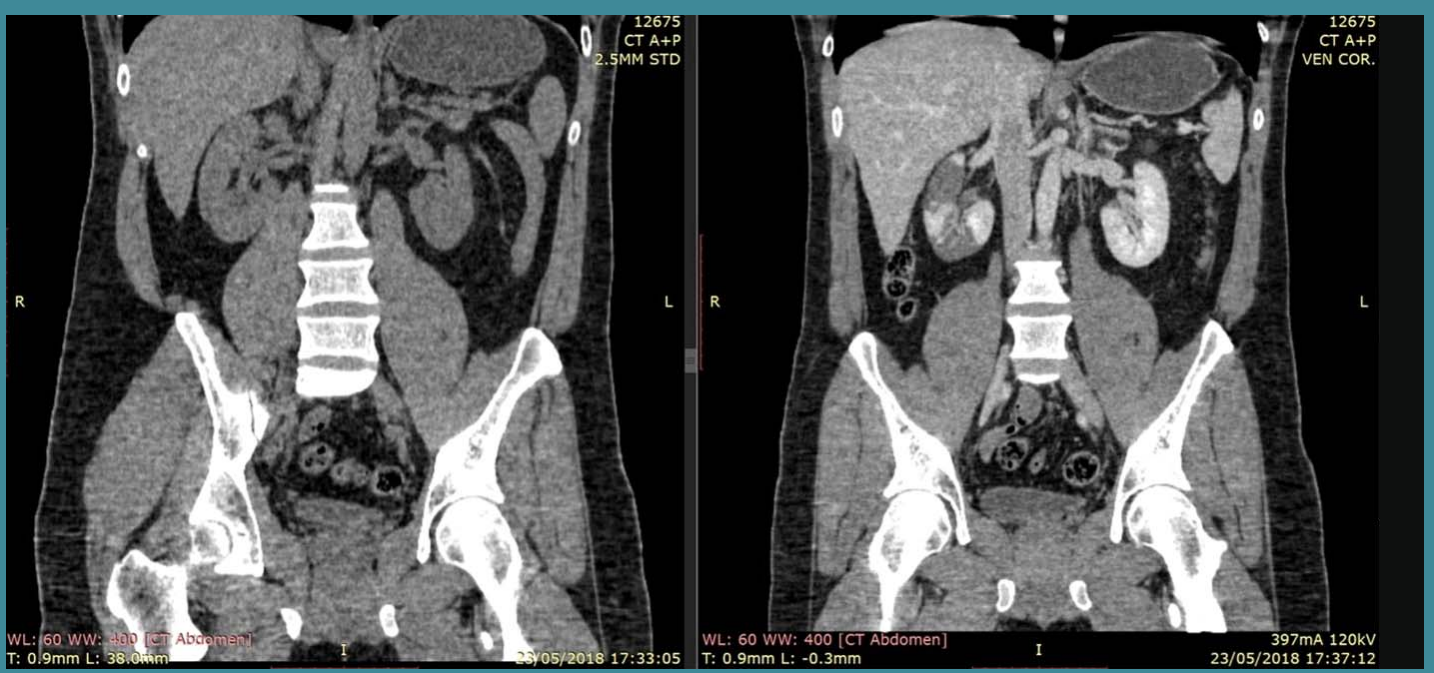

Figure 2. Standard (left) and contrast-enhanced (right) abdominal and pelvic CT scans, coronal section - the two areas of renal infarction can only be seen on the contrast-enhanced scan, whereas on the standard images the kidney appears to be quite normal. 


\section{Discussion}

Renal infarction is a rare pathological event that can present with non-specific symptoms that mimick many other pathologies. Consequently, it can be easily mistaken for a much simpler, self-limiting condition and discarded as such. In cases such as this patient's, the diagnosis can be made even more difficult by the absence of certain elements that would be expected to appear in renal infarctions: haematuria, proteinuria and rise in serum creatinine levels. Literature on the topic is quite limited, most of the studies consisting of retrospective analyses of series of cases. This makes it especially challenging to establish the best course of management for these infrequent patients. However, there is consensus that the first step should be trying to reveal the underlying aetiopathogenesis. The causes can be broadly divided into cardiogenic (mostly represented by atrial fibrillation (AF), which alone is estimated to account for $40-48 \%$ of renal infarction cases, but also including endocarditis, artificial valves, cardiomyopathy), injuries / structural abnormalities of the renal blood vessels (renal artery dissection, trauma, etc.), hypercoagulable states (malignancies, antiphospholipid antibody syndrome, genetic thrombophilic mutations) or idiopathic ${ }^{(2)}$. Afterwards, management is usually wither either anticoagulants or thrombolytic agents, depending on the severity of the situation, with the possible addition of surgical or interventional procedures. Renal artery stenting or antiplatelet therapy may also be considered in the presence of proven atherosclerotic lesions ${ }^{(3)}$.

In this patient, most likely, the cause is the thrombophilic genetic mutations. It could also be argued that the loss of function and structural damage in the left eye that he experienced in early childhood was also due to a thrombotic event. Hereditary thrombophilia is a predisposition towards thrombosis stemming from genetic mutations that alter the delicate balance of clot formation and dissolution in one's organism. Many such thrombophilic mutations have been identified, each having a greater or smaller contribution to the appearance and/or recurrence of thromboembolic events ${ }^{(4)}$. The factor $\mathrm{V}$ Leiden mutation is one of the most common forms of hereditary thrombophilia, increasing the risk of thrombotic events, especially in its G1691A variant, by making factor $\mathrm{V}$ resistant to the inhibitory action of activated protein $\mathrm{C}$. Its heterozygous form is estimated to be present in $2-7 \%$ of the population and to increase the risk of venous thromboembolic (VTE) events 35 times, while its homozygous form is estimated to occur in $0.06-0.25 \%$ of the population and to carry a VTE risk multiplier of $6-19^{(5,6,7)}$.

Mutations in the MTHFR gene lead to a lower than normal production of 5-methyltetrahydrofolate, which is an important methyl 
donor in the conversion of homocysteine to methionine. This may lead to a build-up of homocysteine in the organism, acting as a procoagulant factor through its effects on the endothelium, the platelets and other mechanisms that are not completely clarified as of yet. The most common MTHFR gene mutations are the C677T and A1298C mutations. The true clinical impact of these mutations is controversial. Most studies in literature concur that, individually, being heterozygote for either of them does not translate into a clinically significant increased risk of VTE. However, being homozygote for one of them or being heterozygote for both of them, as is the patient presented above, has been associated with a considerable reduction in MTHFR enzymatic activity ${ }^{(8)}$. It is still uncertain whether this is also associated with a significantly increased risk of thrombosis; this seems to be the case only if elevated levels of homocysteine are truly present is the patient's serum, in which case folate supplements should be considered ${ }^{(9)}$. There is also debate on whether the combination of a MTHFR gene mutation with another, wellestablished, thrombophilic mutation (such as factor $V$ Leiden) further increases the risk of VTE. Although earlier research seemed to point towards this conclusion, many more recent, more rigorous studies, have not confirmed an additionally increased risk of $\mathrm{VTE}^{(6,7,10)}$. Treatment in current thrombophilia guidelines revolves around the VTE event, using rather the same recommendations for anticoagulation as the VTE guidelines for provoked or unprovoked events. However, special attention should be given to thrombotic events in unusual areas ${ }^{(4,11)}$. Commonly, the anticoagulant therapy received is with either a heparin product or a classic oral anticoagulant (acenocumarol or warfarin) as they have the best study results in thrombophilia. Non-anti-vitamin $\mathrm{K}$ oral anticoagulants (NOACs) such as dabigatran, apixaban, rivaroxaban have been considered as an alternative, yet evidence regarding their use in thrombophilia is scarce. However, case reports and post-hoc analyses of thrombophilia subgroups in large VTE studies that used NOAC therapy have shown promising results ${ }^{(12)}$.

Current thrombophilia recommendations do not endorse indiscriminate genetic testing of the patient's family, nor do they support longterm anticoagulation in these relatives if they are asymptomatic. However, high-risk, highpenetration mutations (such as homozygous factor $\mathrm{V}$ Leiden, antithrombin / protein C / protein $\mathrm{S}$ deficiencies) may constitute exceptions and although no clear recommendations can be made, the clinician's judgement should be cautious. In addition, it should be noted that people who have a firstdegree relative with VTE, regardless of the cause, especially if the VTE was unprovoked, do carry a significantly higher risk of having a VTE event themselves. Hence, in high-risk situations that carry additional thrombotic risk (e.g. surgery, long flights, severe infections etc.), anticoagulation is recommended even in these asymptomatic relatives of VTE patients $^{(11,13)}$.

\section{Conclusions}

To summarise, the case report above describes a rather healthy young patient that complained of common, non-specific symptoms, which turned out to have quite a rare cause, two areas of renal infarction in the right kidney. Quite a few frequent clinical and laboratory elements were missing from the patient's presentation, which made the diagnosis even more difficult. The aetiology of the renal infarction itself was an infrequent association of thrombophilic genetic mutations - homozygous factor V Leiden and two MTHFR 


\section{INTERNAL}

\section{Clinical cases}

heterozygous mutations. It is highly possible that the damage he experienced in his left eye when just a child had the same background. Even though current recommendations favour classical anticoagulants, the patient chose to use NOACs, with a favourable outcome to this date. If tested positive for the same mutations, relatives of such patients might choose to undergo anticoagulation, as did the brother, for fear of a VTE event of their own. Such uncommon conditions and situations should be kept in mind by clinicians when analysing clinical cases.

\section{Acknowledgements: none.}

Conflict of Interest disclosure: The authors declare that there are not conflicts of interest.

\section{References}

1. Bourgault M., Grimbert P., Verret C., Pourrat J., Herody M., Halimi J.M. et al. - Acute renal infarction: a case series. Clin J Am Soc Nephrol. 2013; 8(3):392-8.

2. OH Y.K., Yang C.W., Kim Y.L., Kang S.W., Park C.W., Kimet Y.S. et al. - Clinical Characteristics and Outcomes of Renal Infarction. AmJ Kidney Dis. 2016;67(2):243-50.

3. Lengelé J.P., Christophe J.L., Persu A. - Renal infarction management: towards an etiological approach?. Journal of Hypertension. 2018;36(3):490-492.

4. Stevens S.M., Woller S.C., Bauer K.A., Kasthuri R., Cushman M., Streiff M. et al. - Guidance for the evaluation and treatment of hereditary and acquired thrombophilia. J Thromb Thrombolysis. 2016;41:154-164.

5. Campello E., Spiezia L., Simioni P. - Diagnosis and management of factor $V$ Leiden. Expert Review of Hematology. 2016;9:1139-1149.

6. Simone B., De Stefano V., Leoncini E., Zacho J., Martinelli I., Emmerich J. et al. - Risk of venous thromboembolism associated with single and combined effects of Factor $V$ Leiden, Prothrombin 20210A and Methylenetetrahydrofolate reductase C677T: a metaanalysis involving over 11,000 cases and 21,000 controls. EurJ Epidemiol. 2013;28(8):621-647;

7. Gohil R., Peck G., Sharma P. - The genetics of venous thromboembolism. A meta-analysis involving approximately 120,000 cases and 180,000 controls. Thromb Haemost. 2009; 102(2):360-70.

8. Brustolin S., Giugliani R., Félix T.M. - Genetics of homocysteine metabolism and associated disorders. BrazJ Med Biol Res. 2010;43(1):1-7.

9. Moll S. and Varga E.A. - Homocysteine and MTHFR Mutations. Circulation. 2015;132:e6-e9.

10. Salomon O., Steinberg D.M., Zivelin A., Gitel S., Dardik $R$., Rosenberg N. et al. - Single and combined prothrombotic factors in patients with idiopathic venous thromboembolism: prevalence and risk assessment. Arterioscler Thromb Vasc Biol. 1999;19(3):511-8.

11. Maccallum P., Bowles L., Keeling D. - Diagnosis and management of heritable thrombophilia. BMJ. 2014;349:g4387.

12. SkelleY J.W., White C.W., Thomason A.R. - The use of direct oral anticoagulants in inherited thrombophilia. J Thromb Thrombolysis. 2017;43:24-30.

13. Baglin T., Gray E., Greaves M., Hunt B.J., Keeling D., Machin S. et al. - Clinical guidelines for testing for heritable thrombophilia. British Journal of Haematology. 2010;149(2):209-20. 